\title{
"Mine ear is much enamour'd of thy note:" Shakespeare's intercultural dream in the Indian subcontinent
}

\author{
Sofía Muñoz Valdivieso \\ Universidad de Málaga
}

\begin{abstract}
Tim Supple's 2006 production of A Midsummer Night's Dream has been hailed by some critics as the successor of Peter Brook's revolutionary 1970 version, a vision that changed perceptions of the play and became a classic in the history of its performance. Supple's Midsummer uses about half of Shakespeare's English text, with the rest translated into Hindi, Bengali, Marathi, Malayalam, Tamil, Sanskrit and Sinhala. It maintains the plot and characters intact, although it includes elements of local theatrical traditions in music, dance, martial arts and acrobatics. The production defies attempts at classification, since it presents features of "foreign" Shakespeare plays yet it braids the Indianlanguage dialogues into Shakespeare's original English and extends the alienation effect of a foreign language production to audiences throughout the world. The international success of this production since it premiered in Britain as part of the 2006-2007 Royal Shakespeare Company's Complete Works Festival at Stratford is meaningful beyond considerations of aesthetic and theatrical value. The present paper discusses Tim Supple's $A$ Midsummer Night's Dream within the contexts of foreign Shakespearean performance and intercultural theatre, and it analyses the contribution of the production to current debates about the importance of Shakespeare as international cultural capital.
\end{abstract}

KEYWORDS: A Midsummer Night's Dream, intercultural theatre, performance studies, foreign Shakespeare.

Research for this paper was funded by the Andalusian Regional Government (Proyectos de Excelencia de la Junta de Andalucía): Research Project Po7-HUM-02507.

(9) ederi 19 (2009): 99-119

https://doi.org/10.34136/sederi.2009.5 
In 1970 Peter Brook's Royal Shakespeare Company production of $A$ Midsummer Night's Dream was hailed as a watershed in the history of performances of the play, a new way of perceiving Shakespeare's work that would affect its staging for generations to come. More than thirty years later, Tim Supple's 2006 multilingual version of Midsummer seems to have shaken the theatrical consciousness of international audiences and reviewers, and some of them have seen it as the heir to Peter Brook's production. Supple's Midsummer is the result of the work of a multicultural cast of twenty-three Indian and Sri Lankan dancers, musicians and actors who rehearsed in India and performed the play in four Indian cities before they brought it to Britain in June 2006 as part of the Royal Shakespeare Company's Complete Works Festival at Stratford. Around half of the original English text is maintained, so that Supple's production is not an example of "foreign" Shakespeare in the conventional sense, since with seven Indian languages circulating on stage the alienation effect of not understanding the dialogue colours not only the experience of English-speaking audiences, but that of spectators around the world. ${ }^{1}$ To all audiences, including those in India, the words of the play in English, Hindi, Bengali, Marathi, Malayalam, Tamil, Sanskrit and Sinhala remain in part inscrutable and some of its language is perceived, as Stuart Hampton-Reeves states in his review, "as music, because it [cannot] be anything else" (Hampton-Reeves 2007: 200). With no surtitles provided for the performances, the music of the foreign languages necessarily becomes the score that accompanies the visual power of the play, and the surrender of the audience to the magic of the production implies a surrender to the music of its languages that brings to mind Titania's enchantment when, woken up from her bower by Bottom's song, she says "Mine ear is much enamour'd of thy note."

The reactions of critics and reviewers in the international press and in academic journals show that the reception of the play is marked by a celebration of what are perceived as its intercultural values and its ability to breathe new life into Shakespeare's text. Although the play has been praised for its aural originality, the

\footnotetext{
${ }^{1}$ In contemporary India English and Hindi serve as lingua franca, but the other languages are restricted to particular regions, with Sanskrit a classical language of literary texts and rituals but with very few contemporary speakers.
} 
impressions that are used to describe it are mostly visual, and certain adjectives keep resurfacing in descriptions of the production, among them "sensational", "spectacular", "ravishing", "sexy", "entrancing", "astonishing", "vibrant", "exhilarating", "tantalizing", "exuberant", "colourful", and, above all, "exotic". The reception of Supple's Midsummer is not fully disentangled from the contemporary Western consumption of the cultural other as what Graham Huggan has called the postcolonial exotic. The adjective "exotic" is indeed one of the most commonly used in descriptions of what critics have considered a gorgeous spectacle full of energy and colour, and the appeal of the mysteries of the East plays a major role in the attraction that the production has exerted on Western audiences and reviewers. The success of Supple's Indian Midsummer on Western stages is meaningful beyond considerations of aesthetic and theatrical value, and the play can be understood as a contribution to current debates on Shakespeare as international cultural capital and analysed in the context of present discussions over the role of Shakespeare in our contemporary globalised cultural economy.

Michael Billington's raving review of the original Stratford production for The Guardian in June 2006 set the tone for the subsequent reception of the play on stages worldwide: "In its strangeness, sexuality, and communal joy this is the most lifeenhancing production of Shakespeare's play since Peter Brook's" (Billington 2006b). A few months later, Susanne Greenhalgh's review for the Shakespeare Bulletin also mentioned Brook's 1970 revolutionary version of Midsummer and suggested that "Tim Supple's [production] left many in its audience convinced that they had shared in a theatrical event of equivalent artistry and significance" (Greenhalgh 2006: 65). In general, reviewers praised the energy of the production and highlighted its sensuality and exotic beauty, the multicultural approach of its seven Indian languages and its union of East and West theatrical traditions. The very first review that Michael Billington wrote on Supple's version after seeing its initial performance in India a few weeks before its Stratford premiere suggested that, given its particular approach, the production would most likely provoke debate as well as delight and astonishment (Billington 2006a), but the reception of the play in the different locations in Europe, North America and Australia where it has played since its Stratford premiere shows plenty of delight and astonishment but, significantly enough, very little controversy and 
debate. There seems to be a consensus among Western reviewers that the loss of the English text is more than made up by the energy of the production and by the force of the Shakespearean story coming through the foreignness of the actors, their Indian voices and the exotic setting, so that as a whole reviews contribute to the conception that "the performed play transcends, and is transmissible outside of, verbal communication: its dramatic value and power are intrinsic [...] [a] rationale that locates Shakespeare as a universal value which is not culture-specific" (Yong 2005: 529-530).

After its premiere at the Royal Shakespeare Company's Complete Works Festival in June 2006, Tim Supple's Midsummer has been on an international tour that continues at the end of 2008 and it has generally received enthusiastic responses and reviews in every location. Supple's Midsummer was one of the eight plays performed in foreign languages at the Stratford Festival by companies from abroad and, like Twelfth Night, it was the production of an English director with experience working with the Royal Shakespeare Company. The other plays in a foreign language were The Two Gentleman of Verona in Portuguese and English, Henry $V$ in Italian, Othello and Richard III in German, Coriolanus and Titus Andronicus in Japanese, and Twelfth Night in Russian. ${ }^{2}$ With its use of seven Indian languages, Supple's version does produce the distancing effect of foreign takes on Shakespeare, in this case a kaleidoscopic reproduction of a sense of foreignness throughout the globe, with no possible spectator in the world who could understand all the languages that circulate on the stage. The eight plays in foreign languages in the festival were allotted around one sixteenth of the total number of performances, with Midsummer performing on twelve occasions but some other foreign language plays running for only four or five days. Although reviewers seemed to agree that the most innovative productions were those of the visiting companies, the responses to the foreign Shakespeare plays "fluctuated between wary suspicion of what was alien and enthusiastic acclaim for what seemed new" (Parsons 2007a: 7). Of all the foreign-language productions at the festival, Midsummer was by far the most

\footnotetext{
${ }^{2}$ For an analysis of the foreign language plays at the festival see Parsons (2007a). For a general review of the festival see the special 2007 issue of Cahiers Élisabéthains: A Biannual Journal of English Renaissance Studies and Michael Dobson's "Shakespeare's Performances in England, 2006" (2007).
} 
successful with audiences and critics, and some of them perceived it as the most striking and inventive contribution to the Complete Works Festival (Hampton-Reeves 2007: 200). ${ }^{3}$

Tim Supple is a highly reputed English director who has worked with the Royal National Theatre and the Royal Shakespeare Company and is known for "his commitment both to vivid, stripped-to-essentials story-telling and cross-cultural exploration" (Greenhalgh 2006: 65). Among his former intercultural works we find the adaptation of Salman Rushdie's Haroon and the Sea of Stories for the RNT in 1999 and Midnight's Children for the RSC in 2003, as well as a multicultural television version of Twelfth Night for Channel 4 in 2003 that was resonant with the themes of immigration and integration in contemporary Britain. A Midsummer Night's Dream should thus be seen in the context of Tim Supple's career as a multicultural director who enjoys taking classics and giving them a new spin and who has a particular link with Indian cultures, as shown by his previous transposition to the theatre of Salman Rushdie's work. ${ }^{4}$ The seeds of the project of an Indian Midsummer Night's Dream were planted at the end of 2004, when Tim Supple received a call from the British Council in Delhi and a request to put together "a large scale work with popular potential that embraces artists from different regions" ("British Council India"). In early 2005 different possible productions were being considered as Supple was travelling around India to become familiar with theatrical traditions and to meet local directors, performers and designers. He was already aware at the time that if he were to choose a Shakespeare play the Royal Shakespeare Company would be interested in inviting it to Stratford as part of the Complete Works Festival. He has explained in interviews that Midsummer was a play that he had wanted to do at some point but "had no particular passion about

\footnotetext{
${ }^{3}$ Supple has expressed his astonishment at the reception: "I told the cast not to expect standing ovations at Stratford as I had never seen one for a Shakespeare production [...] it was a really, really moving occasion for us and the audience too when at the end they just stood and roared [...]. I wasn't just surprised. I was overwhelmed. That happened at every one of the 12 performances" ("A Midsummer Night's Dream Journalist Resource Pack").

${ }^{4}$ In the case of A Midsummer Night's Dream he had special challenges working with a multilingual cast, some of whom do not speak English -he admits that he was unable to communicate directly with all the cast members and his comments and instructions had to be translated.
} 
doing [...] in a British context" (Cornwell 2008). After his immersion in Indian theatrical practices in early 2005 and his resolution to produce Midsummer, he decided that his version would combine the Western tendency to portray realism and psychological truth with the Indian theatrical ability to better represent "the ritualistic and ancient side" (Cornwell 2008) of Shakespeare. ${ }^{5}$

Tim Supple has not been very explicit about the overall vision of the play that guided him when assembling the performers, and in interviews he has frequently mentioned that the production reflects the multilingual multicultural situation of contemporary India, but he has rejected the idea that it may say anything else about India: "Everything about the show comes out of India but it's not making comments about India or trying to understand India in a superficial way" (Cornwell 2008). ${ }^{6}$ It is nevertheless inevitable that international audiences should feel that they are receiving some representation of India in the performance, and the production is not fully free of the dangers of consuming India as the postcolonial exotic, since audiences may walk away from this magic play with a renewed sense of the mysterious and enchanting nature of Indian culture and an image of the location and its people as exuberant, colourful and impenetrable -these were indeed the concerns that a few local critics expressed after the first performances of the show in India, when they "suggested that the play was a piece of exotica that would go down best with foreign audiences [and] asked whether the production's stress on eroticism, savagery and primitive ecstasy reinforced colonial stereotypes" (Billington 2006a). Western critics do highlight the exotic and mysterious nature of a production in which "the sets, the costumes and the performances [are] exotic, sensuous and as mysterious as the many languages $[\ldots]$ that the actors [speak]"

\footnotetext{
${ }^{5}$ Supple is excited about the transformation he produced in the performers: "'The sex! The violence! The emotional truth! [...] At the beginning of rehearsals, hardly any of these actors would have expressed those things realistically and literally as they do in the show'" (Cornwell 2008). The pull toward realism results in a sexual physicality on stage that was excessive for many women auditioning for the roles (as well as for some Indian spectators), since it goes so very much against Indian social habits and acting styles, both on stage and in films.

6 “'It's never for me about the novelty [...]" says Supple addressing the possibility that this staging might be accused of exoticizing its performers, or repeating colonialist patterns. 'What is important is making possible a way of discovering what's in the play'” (Balser 2008).
} 
(Hampton-Reeves 2007: 200; emphasis added). Western audiences lack an informed understanding of the specific aspects of Indian cultures that are integrated into the production and, as a result, the overall impression they may indeed have after the performance is a sense of having witnessed a set of magic transformations that are only vaguely understood as enchanting and ravishing to the senses an effect that is in keeping with the Shakespearean text, but which may be entangled in perceptions of India as a whole as enchanting and ravishing, exotic and distant.

Most reviewers seem to be unaware of the danger of a renewed Orientalism that may lie behind the celebration of the mystery and the sensuality of the Indian performers, that is, the Western consumption of the cultural other as what Graham Huggan calls the postcolonial exotic -and even if they hint at its possibility they immediately dismiss it without any in-depth discussion, enchanted as they are by the theatrical magic that the production does conjure up in its deployment of the charm and the beauty of the East. ${ }^{7}$ Michael Dobson's review for the Shakespeare Survey can be an example of the incomplete analysis of the dangers of exoticism in the performance even when they are acknowledged. He mentions what he calls a possible "uncharitable account of this production" (Dobson 2007: 301) which might describe it in the following terms:

Tim Supple had been given a budget to travel around the Indian subcontinent cherry-picking the best talents in a range of local types of performance and then simply gone through the script of A Midsummer Night's Dream deciding where they could each show off their respective acts to best effect, thereby assembling a show masquerading as a Shakespeare revival but really offering a composite, exoticized vision of India for audiences of de facto tourists. (Dobson 2007: 301)

The possibility for criticism is introduced, although Dobson immediately adds that this critique is difficult to sustain because, despite offering many of the pleasures of the exotic, the production "does ground itself in an intelligent, original and cogent reading of

\footnotetext{
7 Occasionally, the idea that we may be facing a production that exploits the popularity of Bollywood and all things Indian in the West is directly addressed by reviewers. Richard Ouzounian, for instance, energetically rejects it when he says: "This is no gimmicky production in which Indian trappings have been grafted onto Shakespeare's play for trendy appeal" (Ouzounian 2008).
} 
the play" (Dobson 2007: 302). The reviewer himself sounds seduced by the visual power of a performance in which gazing upon the beauty of the Eastern other on stage seems to determine an important part of the aesthetic pleasure it generates, with Dobson explicitly acknowledging that the production is "consistently enjoyable -not least, frankly, because its cast are all unnaturally goodlooking and wear few clothes, and those beautiful" (Dobson 2007: 302; emphasis added). Indeed, Dobson only mentions and briefly describes one aspect of what he calls the original cogent reading of the play: its closeness to Così fan tutte in its suggestion that, when faced with a real chance, all the characters are likely to find adherence to monogamy difficult, so that the reunion of the couples and all the other disparate elements of this production in Act V is both a relief and a miracle (Dobson 2007: 302).

There are few reviews that look into the braiding of East and West in the play in detail, as does Susanne Greenhalgh writing for the Shakespeare Bulletin. Her review discusses relevant examples of the performance traditions of contemporary South Asia that are used in the production, from the martial art of Kalarippatayyu to the Sanskrit hymns that accompany most Hindu weddings. Her analysis of the production is a reasoned assessment of the Indian cultural elements that are at work in Supple's version and it offers an overall evaluation of the performance that goes beyond praising the original mingling of languages in the play and its visual ravishing of the audience. Part of the exhilaration that most reviewers express when describing their experience of the play has echoes of John Russell Brown's depiction of the critic's reaction to Shakespearean productions in which the language is not understood: "A new sense of what had hitherto lain hidden begins to emerge from within the familiar Shakespeare text [...]. The critic comes away with an enthusiasm not easy to explain" (Brown 1993: 21). With around half of the text in English, however, Tim Supple's Midsummer is an unusual example of "foreign" Shakespeare and it has been frequently perceived as an intercultural Shakespeare play which maintains characters and plot intact but presents them in a conglomerate of English and Indian languages and theatrical styles. He does not alter the text other than to translate it into the different Indian languages that each member of his cast feels is most natural for him or her, and he himself has described his version as a very faithful line-by-line production. Tim Supple's comments on the 
conception of the project are in this sense very revealing of his approach to intercultural theatre in his Indian Midsummer: "[T]he thing that led my interest was a desire to hunt out theatre of a very different texture than our (British) theatre [...]. In the West we are much better at servicing the modern side of Shakespeare [...] but we're out of touch with the ritualistic and ancient side" (Cornwell 2008; emphasis added). We could say that Tim Supple chooses without hesitation one of the two contrasting ways of understanding Shakespeare across cultures that Yong $\mathrm{Li}$ Lan describes in "Shakespeare and the Fiction of the Intercultural", that is, as an approach "centered in the text, which is taken as a stable entity that is refracted and enriched by the performance forms and perspectives of the other cultures" (Yong 2005: 539) -an approach that contributes to the sense that Shakespeare is a timeless universal value. The other way to understand the bard across cultures is described as "a decentering foreignness, a strategic disruption of 'Shakespearean' meanings, and of the cultural power they evoke, through the deployment of a performance system that challenges the integrity, identity and singularity of 'Shakespeare'" (Yong 2005: 539-540). ${ }^{8}$ The successful international career of Tim Supple's Midsummer so far confirms that most audiences and critics are in tune with this vision of the Shakespearean text as a stable cultural entity that performance structures from other cultures serve to enrich and breathe new life into.

It is not easy to summarize the magic of the production that has captivated audiences and reviewers around the world and brought comparisons with Peter Brook's 1970 vision. ${ }^{9}$ As in Brook's conception, the scenography is kept simple, the result of a process of sketching and trying many things in the search for "something light, simple and suggestive" (Bate and Rasmussen 2008: 123). While Brook presented all the action in a white cube that was always under powerful white light, in Supple's production the lighting effects contribute greatly to the changing of locations from the day world of

\footnotetext{
${ }^{8}$ This distinction between universalizing and disruptive approaches to Shakespeare intercultural theatre has a lot in common with what other critics describe as celebratory vs. oppositional appropriations of Shakespeare's works.

${ }^{9}$ Details of the production in the present paper make reference to the performances of the play by the company at the Currant Theatre in San Francisco between 16 May and 1 June 2008.
} 
the Athenian court to the dark and frequently nightmarish world of the wood or to the misty morning ambiance of the post-dream awakenings in IV.i. When the action begins in the Athenian palace with Theseus and Hippolyta delivering a couple of Shakespearean lines before quickly shifting into Malayalam, Athens is a silverfloored open space with a white back wall that is meant to suggest "something classical and solid" (Bate and Rasmussen 2008: 123). This wall is mounted on a bamboo scaffolding that will be later revealed and used extensively in the performance, and its apparently solid surface proves to be a thin film of white paper that will be ripped through when the fairies burst in from the back in II.i. and jump onto the ground of the wood -a powerful image of the very fine screen that separates the fairy world from the human world. The floor by then is no longer the sophisticated silver surface of Theseus's palace, since with the entrance of the mechanicals in I.ii the ground silver covering has been removed to reveal red Indian soil. Throughout the performance three musicians are on the sides of the stage as witnesses of the actions, creating a musical environment for the story and punctuating it on occasion with flute, guitar and percussion instruments.

Maintaining Peter Brook's now classic doubling of Theseus/Oberon, Hippolyta/Titania and Philostrate/Puck, this production begins with Philostrate (Ajay Kumar, who also plays Puck) as a master of ceremonies that plays a singing stone located in a small pool of water downstage, conveying the sense that in court as in the wood there is a stage manager controlling the performance. Ajay Kumar's incarnation of the knavish sprite is a deliciously wicked combination of "punk trickster, fertility god and Indian fakir" (Greenhalgh 2007: 68). Dressed in a red loincloth and with a permanent mischievous grin of enjoyment, he is frequently present on stage as an observer of the actions of the high and low Athenians, and he particularly seems to relish the confusion of the lovers in the wood. This is indeed one the most visually powerful moments in the play, when the four lovers become entangled in a cat's cradle of elastic rope that Puck slowly but relentlessly weaves around them as their disagreements grow into a verbal and then a physical fight in III.ii -the elastic trap a compelling embodiment of their rising confusion in the wood before they fall asleep and wake up to a new perception of themselves and their situation. Indeed a crucial part of the production's magnetism arises from the vigorous materialization 
of the wood as it comes alive through the wicked playful presence of the fairies. While the Athenians are dressed in luscious contemporary Indian clothes with a flavour of timelessness and a whiff of old, and the mechanicals in easily recognizable contemporary clothes so that they "bring a reality to the stage and [...] convince as working men from India's streets" (Bate and Rasmussen 2008: 134), the fairies are dressed in black with much of their flesh on display, their acrobatic bodies another contribution to the circulation of sensuality on the stage as the silvery light of the watery moon shines over the wood's confusion. As Supple himself indicates, "our fairies wear as few clothes as possible, all black [...] Flesh and muscle, legs, backs and arms: these are the key elements of our shadows' costumes" (Bate and Rasmussen 2008: 149). Like Peter Brook, Tim Supple conceives the fairies as performers, in this case scantily dressed acrobats and popular entertainers from Indian cultures.

The magic world of the forest comes alive with particular force in its first appearance, when loud and whirling fairies burst through the white back wall of Athens in II.i and the wood suddenly manifests itself as a place of danger and mysterious beauty. The acrobatic spirits bring to life the night forest at other significant moments, as when they create the confusion of the wood for the rehearsing mechanicals in III.i (or for Hermia after waking up from her nightmare in II.ii) by holding big leaves and canes over their heads -just as Peter Brook's fairies held at times entwined blocks of wire over the mechanicals to suggest the natural surroundings. There are several playful fairy interventions in the actions of the humans in the wood, such as the spirits' bringing down long bands of red silk that they offer as forest beds for Lysander and Hermia in II.ii, with Peaseblossom flirtatiously enticing Lysander to his resting place. Like Peter Brook, Tim Supple makes use of the verticality of the stage in his inclusion of these descending red silk bands as the lovers' bed and Titania's bower, but mainly in the fairies' expression of the magic world of the wood through acrobatic exercises, which are also part of Titania and Oberon's Indian boy's gymnastic performance -indeed one of the most widely used pictures of the production in reviews shows Titania as she is wrapping herself up in her red-silk bower-cum-sari, an image that captures the acrobatic nature of the performance and suggests its Indian grounding. Archana Ramaswamy, who is a trained classical dancer in 
Bharatanatyam, is a fiery Titania worthy of her equally physical Oberon, performed by the actor P. R. Jijoy, who is also trained in various forms of martial arts, dance and music. Both transform themselves from fairy creatures to courtly characters in front of the audience, donning their more elaborate costumes as Theseus and Hippolyta as they finish delivering their lines as Oberon and Titania. The stage presence of Titania/Hippolyta is particularly engaging with English-speaking audiences since like other women characters in the production she is assigned more lines of the original Shakespearean text than the male characters, which makes her words more easily available in the midst of the Indian languages. ${ }^{10}$

In keeping with most post-Brook stage readings of Midsummer, Tim Supple's play presents the sensuality in the wood in its darkest hues, and the production is in fact rather more sexually explicit than can be expected from an Indian performance, not only in the open sexuality of Bottom (with donkey's ears and a big calabash as an enormous phallus he cannot manage to hide), or in the fairy encounters of Titania with her own husband, in which their argument has them "rolling on the stage, with their bodies locked together" (Parsons 2007b), but also in the case of the young lovers, who are very physical on the stage and end their night misadventures in the wood partly naked. The magic juice of the love-in-idleness flower -red powder that covers Lysander's and Demetrius's eyes and brows as the colours applied during Hindu festivals- brings out their lust, not their love, as they pursue the young girls in the confusion of the night wood. On the other hand, and also like Peter Brook, Supple chooses to take the mechanicals' performance seriously, so that they are not played for easy laughs but as craftsmen who put all their energy into a production that partly succeeds and is much more than pure farce. The mechanicals do look like contemporary Indian craftsmen and workers and like the high Athenians, most of them also participate in the polyphonic ensemble that moves Shakespeare's lines from English to some regional Indian language, Marathi for Bottom (Joy Fernandes) and Bengali and Hindi for Flute (Joyraj Bhattacharya). Joy Fernandes has

\footnotetext{
${ }^{10}$ The women in the production do speak more English lines than the other characters. This distribution was not intentional, but a result of the casting of the actresses since, as Supple indicates, "[a] lot of women in India would not have been able to engage physically on stage [...] as I felt it had to be done" (Padmanabhan 2006).
} 
been highly praised for his incarnation of Shakespeare's weaver as comic yet contained, "a sweetly serious Bottom [...] that is both wonderfully funny and faintly disturbing" (Munro 2007: 20) and his performance has been seen as epitomising the virtues of the production, since he has "weight, dignity, and the total dedication of the artisan-turned actor" (Billington 2007a).

When asked by an interviewer in Australia about Shakespeare's possible reaction to this "gorgeous, globalized version" of Midsummer (Cornwell 2008), Tim Supple's response points to his sense that it maintains the essence of the play: " $[\mathrm{H}] \mathrm{e}$ 'd recognise the heart and soul of the production and its physicality. He'd see himself there on the stage in the dust and the earth" (Cornwell 2008). Supple's Midsummer seems to be thus another confirmation that foreign performances of Shakespeare can attest to the mesmerizing power of his plays that defies their removal to local stages and foreign languages, a secret quality "which is not destroyed by adaptation, transposition, misrepresentation, spectacular simplification, or novel accretion" (Brown 1993: 22). Tim Supple's Midsummer has been conceived by the director and received by audiences and critics as a magic play whose power is better expressed in terms of antitheses: it is foreign yet authentic, exotic yet truly Shakespearean, distant yet uncannily close, and, as Billington suggested, securely rooted in Indian experience and at the same time paradoxically airborne (Billington 2006a).

The study of "foreign" Shakespeares is a relatively recent phenomenon, particularly when it comes to performance, since the field itself of Shakespeare in performance has developed in recent years, beginning with its (partial) institutionalization in the early eighties (Hodgdon 2005: 2). In his introduction to the pioneer volume Foreign Shakespeare (1993), Dennis Kennedy stressed the scant attention that English-language criticism of the plays had paid to foreign productions of Shakespeare and he described his volume on foreign Shakespeare as "an introductory project" (Kennedy 1993: xvii). The book blurb itself described it as the first collection to offer a considered account of contemporary Shakespeare performance in non-English-speaking theatres. Kennedy acknowledged the contribution of foreign productions to new understandings of the plays, given that they cannot place "the same emphasis on Shakespeare's verbal resourcefulness" and therefore are bound to 
explore "scenographic and physical modes more openly than their Anglophone counterparts, often redefining the meaning of the plays in the process" (Kennedy 1993: 6). He felt at the time that the book's concentration on European performances was justified since most of Shakespeare production outside English still took place in Europe, and European theatres led the way in redefining performance models (Kennedy 1993: xvii-xviii).

The visibility of foreign Shakespeare performances, including non-European productions, and the interest aroused by them among scholars and general audiences has increased considerably since Dennis Kennedy gathered the material for his book, and less than a decade after its publication a general volume on Shakespearean performance such as The Cambridge Companion to Shakespeare on Stage (2002) devotes three of its fifteen chapters to non-English-language performances ("International Shakespeare", "Shakespeare on the Stages of Asia" and "Shakespeare and Africa") and significantly boasts on its cover a photograph of Jiang Weiguo's 1986 production of Much Ado About Nothing as background for the inset picture of the 2000 RSC production of Henry IV, part 2. As Barbara Hodgdon indicates, in the new millennium "the critical project of studying Shakespeare performances has come of age" (Hodgdon 2005: 7), and foreign performances are no longer in the periphery of this field of study. There are indeed many indications of this development -in which an important role has been played by the consolidation of the field of Shakespeare on film. Thus several of the performance books that Kennedy mentions in 1993 as not including information on foreign Shakespeares have been adding it in their new editions, for instance a chapter on Chinese productions in the case of Jay L. Halio's 2003 Midsummer volume for the Manchester University Press "Shakespeare in Performance" series. Hodgdon's volume Shakespeare and Performance (2005) announces the plan for another version of Kennedy's volume, Foreign Shakespeare 2: Performance in the New Asia co-edited with Yong Li Lan (Hodgdon 2005: Xv), and in recent years there has been a proliferation of publications on varied aspects of Shakespeare's productions in the world, from those dealing with specific locations, such as Murray J. Levith's Shakespeare in China (2004) or Poonam Trivedi and Dennis Bartholomeusz's India's Shakespeare: Translation, Interpretation, and Performance (2005), to those which attempt to bring together global and local Shakespeares such as Sonia Massai's World-Wide Shakespeares: Local Appropriations in 
Film and Performance (2005) or Martin Orkin's Local Shakespeares: Proximations and Power (2005). As the editors of Native Shakespeares: Indigenous Appropriations on a Global Stage (2008) indicate, "[ $\mathrm{t}]$ here has been, in the last 10 years, an explosion of critical interest in the way that Shakespeare has been made to accommodate local cultures across the globe" (Dionne and Kapadia 2008: 5). A defining feature in the evolution of the field of non-English Shakespeare is the change of perspectives embodied in the nomenclature, from Kennedy's "foreign Shakespeare" in his 1993 volume to Sonia Massai's "worldwide Shakespeare", Martin Orkin's "local Shakespeares" or Craig Dionne and Parmita Kapadia's "native Shakespeares" in the new millennium. The relocation of the source of scholarship and study from Britain to global or local perspectives is clearly embodied in the shift from the term "foreign" in Kennedy's volume to the expressions "world-wide", "global" and "local" in more recent books, an indication of the movement both of performances and of scholarly and critical tasks away from the cultural centre of Britain and onto the world stage and the different local stages.

This explosion of interest in foreign, world-wide, global and local Shakespearean productions in the publishing world in recent years is part of the decentralizing movement in Shakespearean studies from traditional scholarly discussion of the plays as repositories of English and universal values towards the celebration of what we could call the carnivalization of Shakespearean studies, that is, the rising importance of scholarly discussions of issues that until the last years of the twentieth century would have been considered unworthy of academic study, such as Shakespearean plays on film and other visual media, textual poaching of Shakespeare's work through popular culture appropriations, and the proliferation of local Shakespeares that shape a multifarious global Shakespeare of kaleidoscopic irreverent forms. Tim Supple's production comes at a moment of intense awareness of the interplay between the local and the global, a moment of glocalized cultures in which artistic products can be promoted internationally by highlighting precisely their local values. The contending forces of the global and the local find their peaceful entendre in the fruitful notion of "intercultural theatre", the sense that the combining of two or more local tendencies can yield a chance for mutual enrichment and, in the case of the long dominant British cultural icon William Shakespeare and the cultural traditions of former countries of the 
empire such as India, lead to a productive balance of the previously uneven cultural power play of colonizing and colonized people. As Parmita Kapadia indicates, the interest in "theatre that deliberately negotiates between distinct cultural boundaries" (Kapadia 2008: 95) has resulted in the proliferation of terms to describe it, including "postcolonial", "intercultural", "cross-cultural", "syncretic", "multicultural" and "transcultural". The more enthusiastic among critics of Tim Supple's production have raved about its mingling of traditions, which make of it, in the passionate perception of Richard Ouzounian for The Toronto Star, "an astonishing theatrical experience in which East and West totally unite" (Ouzounian 2008). The interculturality of Supple's version is perceived as a given and, with few exceptions, reviewers do not express any concerns for possibly exoticizing readings of the production, nor do they seriously scrutinize what this all-Indian version of Midsummer tells the audience about the Indian subcontinent beyond their celebration of the multilingual cast. They seem to be satisfied with interpreting the production as the combination of Supple's English vision and the energy of the Indian performers, in Billington's words, "a collaborative alliance between Supple's English sensibility and the particular skills of the south Asian actors" (Billington 2006a).

To understand the magic exerted by the production on critics and audiences it helps to place Tim Supple's A Midsummer Night's Dream in the history of the play in performance, from musical extravaganza in the seventeenth century and operatic and ballet spectacle in the eighteenth and nineteenth centuries to twenty-first century visions. This history has been seen as a repeated polarization between two extreme interpretations: "the 'traditional' (both innocent and pictorially elaborate) and the 'modernist' (represented pre-eminently by Brook's landmark RSC production of 1970, obsessively re-engaged in subsequent productions)" (Shaughnessy 2005: 112). The perception of a dark side to the magic world of the Athenian wood only emerged on stage in the sixties in a development parallel to the pessimistic view of the comedies in Jan Kott's Shakespeare Our Contemporary (1964). Inspired by Kott's vision, Peter Brook's 1970 production of the play received in its own time exalted praise (and some severe criticism) and has become a classic in its own right, a conception of the play that captured not only the vision of its director but the spirit of the times. Part circus entertainment, part minimalist distillation of Shakespearean values, 
the production managed to unite the contemporary energies of the hippie movement with the darker possibilities in the play and an original scenography that, in its combination of stark white emptiness and colourful simplicity, captivated the imaginations of contemporary audiences and future generations of Shakespearean directors.

The success of Tim Supple's play with audiences and critics throughout the world lies in a similar combination of factors. On the one hand, his vision of Midsummer manages to unite elements of what Shaughenessy calls the two polarized stage interpretations of the play, the "traditional" and the "modernist" readings -he displaces the musical magic of the wood to the non-English and exotic sounds and forms of Indian music and dance, and therefore distances for Western audiences what may be considered the more sentimental aspects of the play; at the same time, however, he highlights the modern reading of the wood as a dark place of savagery and danger, with "an ability to bring out the demonic otherness of the Athenian wood" (Billington 2007a) that has been extremely appealing to critics, crucially because this demonic otherness is both dangerous and attractive. As the reviewer for the Times Literary Supplement puts it, Supple's production "demonstrates with wonderful ease and dignity both the joyous lightness and the erotically charged darkness of this remarkable play" (Lucy Munro 2007: 20; emphasis added). On the other hand, by employing an allIndian cast and combining theatrical traditions of East and West, his production responds to twenty-first century interest in international, intercultural Shakespeares that manifest the forces of the local and the global in the world. Supple's production elaborates the tendency to bring into the performance of Shakespeare elements of other theatrical traditions that was already present in Peter Brook's, a tendency that according to Barbara Hodgdon is fully developed in the mid-nineties, when "whether drawing from Brecht, Beckett, Noh, Kabuki or kathakali, Shakespearean performances increasingly and freely borrowed, assimilated and reworked theatrical traditions" (Hodgdon 2005: 5). Peter Brook's production was a child of the sixties that has managed to remain fresh and engaging for subsequent generations of critics. Tim Supple's Midsummer is also a product of our times, a play that is presented and perceived as intercultural in its mingling of languages and theatrical traditions, and embodies the sense of Shakespeare as international cultural 
capital that can circulate throughout the world, as it displays for international audiences a version of the play that claims to reach to the very essence of Shakespeare by removing his story to an Eastern location and his text to a multiplicity of Indian languages.

Only time will confirm whether Tim Supple's A Midsummer Summer Night's Dream is indeed the successor of Peter Brook's as the revolutionary production that can become a major influence on the contemporary stage. In our view, the play is most accurately described as a multicultural production in which different languages are mixed on the stage and elements from diverse Indian performance traditions are incorporated. It provides a dream of interculturality in the possibility of an even partnership between different cultural traditions, but it is not truly intercultural in the performance terms defined by Chinese director David Jiang as requiring "painstakingly minute negotiations between often opposed preconditions and conventions that characterize the target and the source cultures" ( $\mathrm{Li}$ 2005: 40). There is no attempt to achieve an equal relation between English and Indian traditions, and their interaction does not strive to be balanced: as in the case of other Western directors in the past, the performance traditions of the East are there to bring new life to the Shakespearean text -as Supple has insisted, "[w]hat is important is making possible a way of discovering what's in the play'" (Balser 2008). The production could be seen as intercultural theatre within the model proposed by Patrice Pavis, which typically assumes a European audience and encompasses exchanges between cultures that are mostly a one-way movement from East to West. The colonial and orientalist potential of this theory of interculturality has been denounced by critics like Rustom Bharucha, who offers an alternative model which envisions intercultural theatre as "a two-way street where the cultural sources are equally respected and theatre practitioners collaborate, moving back and forth with awareness of power differentials, to achieve consensus" (Daugherty 2005: 54). Tim Supple's production creates the illusion of an intercultural performance, a dream that vanishes as we reflect upon what we have seen on the stage: it is indeed polylingual and multicultural, since different Indian languages and elements from Indian traditions are given a place in the performance. The audience is mesmerized into perceiving they are watching an intercultural exchange of Eastern and Western traditions but this interaction is profoundly unequal -the Indian 
performers and their skills are at the service of the greater value of Shakespeare. In fact the claim is made that the effect of using Indian performance styles has been paradoxically to bring out the essence of Shakespeare, not to change it in any way. This is indeed one of the ways in which Shakespeare still circulates as cultural capital in our globalised cultural economy, with the elements of other cultures strategically deployed to breathe new life into the ancient body of the Bard.

\section{References}

Anon. 2007. "Tim Supple's Midsummer Night's Dream Goes on Tour" The Watford Observer 21 September.

<url: http://www.watfordobserver.co.uk/news/1705846.print/>

"A Midsummer Night's Dream Journalist Resource Pack." Luminato Festival, Toronto.

<url:http://ww.luminato.com/festival/eng/designedit/upload/A_Mid summer_Night\%20s_Dream_JOURNALIST_RESOURCE_PACK.doc $>$.

Balzer, David 2008. "British Director Tim Supple's Strange and Surprising Dream Lands at this Summer's Luminato Festival." Eyeweekly 28 May. <url: http://www.eyeweekly.com/features/article/29036>.

Bate, Jonathan and Eric Rasmussen 2008. "A Midsummer Night's Dream in Performance: The RSC and Beyond." Eds. Jonathan Bate and Eric Rasmussen. A Midsummer Night's Dream. London: Macmillan: 94-150.

Bharucha, Rustom 1993. Theatre and the World: Performance and the Politics of Culture. London: Routledge.

Billington, Michael 2006a. "Indian Summer." The Guardian 31 May. <url: http://www.guardian.co.uk/stage/2006/may/31/theatre.india>.

Billington, Michael 2006b. "A Midsummer Night's Dream, Swan, Stratford." The Guardian 9 June.

<url: http://www.guardian.co.uk/stage/2006/jun/og/theatre.rsc>.

Billington, Michael 2007a. "A Midsummer Night's Dream." The Guardian 14 March.

<url: http://www.guardian.co.uk/stage/2007/mar/14/theatre1>

Billington, Michael 2007b. "The Delights and Dangers of Touring Shakespeare." The Guardian 15 November. <url:http://www.guardian.co.uk/stage/theatreblog/2007/nov/15/the delightsanddangersofto $>$.

"British Council India: A Midsummer Night's Dream, Directed by Tim Supple" 
<url:http:/ / www.britishcouncil.org/india-connecting-north-march2006-tim-supple1.htm>.

Brown, John Russell 1993. "Foreign Shakespeare and English-Speaking Audiences." Ed. Kennedy, Dennis. Foreign Shakespeare: Contemporary Performance. Cambridge: Cambridge University Press: 21-35.

Cornwell, Jane 2008. "A Dream from Afar." The Australian 26 January. <url:http:/ / www.theaustralian.news.com.au/story/o,25197,230910335013570,00.html>.

Daugherty, Diane 2005. "The Pendulum of Intercultural Performance: Kathakali King Lear at Shakespeare's Globe." Asian Theatre Journal 22/1 (Spring): 52-72.

Dionne, Craig and Parmita Kapadia 2008. "Introduction." Eds. Craig Dionne and Parmita Kapadia. Native Shakespeares: Indigenous Appropriations on a Global Stage. Aldershot: Ashgate: 1-15.

Dobson, Michael 2007. "Shakespeare Performances in England, 2006." Shakespeare Survey 60: 284-319.

Greenhalgh, Susanne 2006. "A Midsummer Night's Dream." Shakespeare Bulletin 24/4 (Winter): 65-69.

Hampton-Reeves, Stuart 2007. "Review of A Midsummer Night's Dream (directed by Tim Supple) at the Swan, June 2006 and the Roundhouse, London, April 2007." Shakespeare 3/2 (August): 200-202.

Hodgdon, Barbara 2005. "Introduction: A Kind of History." Eds. Barbara Hodgdon and W.B. Worthen. A Companion to Shakespeare and Performance. Malden, MA: Blackwell: 1-9.

Huggan, Graham 2001. The Postcolonial Exotic: Marketing the Margins. London: Routledge.

Kapadia, Parmita 2008. "Jatra Shakespeare: Indigenous Indian Theater and the Postcolonial Stage." Eds. Craig Dionne and Parmita Kapadia. Native Shakespeares: Indigenous Appropriations on a Global Stage. Aldershot: Ashgate: 91-103.

Kennedy, Dennis ed. 1993. Foreign Shakespeare: Contemporary Performance. Cambridge: Cambridge University Press.

Levith, Murray J. 2004. Shakespeare in China. London: Continuum.

Li, Ruru 2005. "Negotiating Intercultural Spaces: Much Ado About Nothing and Romeo and Juliet on the Chinese Stage." Ed. Sonia Massai. World-Wide Shakespeares: Local Appropriations in Film and Performance. London: Routledge: 40-46.

Munro, Lucy 2007. "Translated from Top to Bottom." Times Literary Supplement 23 March 20. 
Orkin, Martin 2005. Local Shakespeares: Proximations and Power. London: Routledge.

Ouzounian, Richard 2008. "New Multicultural Adaptation of the Bard's Magical Play Seemed Tailor-Made for Toronto." The Toronto Star 31 May. <url: http:/ /www.thestar.com/Entertainment/article/433711>.

Padmanabhan, Mukund 2006. "In Conversation". The Hindu, 2 April. <url:http://www.thehindu.com/thehindu/mag/2006/o4/o2/stories/2 oo6040200100200.htm>.

Parsons, Elinor 2007a. "'This wide and universal theatre': Shakespeare in Different Voices." Eds. Peter J. Smith and Janice Valls-Russell, with Kath Bradley. Cahiers Élisabéthains: A Biannual Journal of English Renaissance Studies. Special Issue: 7-11.

Parsons, Elinor 2007b. "Review of A Midsummer Night's Dream." Eds. Peter J. Smith and Janice Valls-Russell, with Kath Bradley. Cahiers Élisabéthains: A Biannual Journal of English Renaissance Studies: 38-39.

Pavis, Patrice 1992. Theatre at the Crossroads of Culture. Trans. Loren Kruger. London: Routledge.

Shaughnessy, Robert 2005. "Dreams of England." Ed. Sonia Massai. WorldWide Shakespeares: Local Appropriations in Film and Performance. London: Routledge: 112-121.

Trivedi, Poonam and Dennis Bartholomeusz eds. 2005. India's Shakespeare: Translation, Interpretation, and Performance. Newark: University of Delaware Press.

Yong, Li Lan 2005. "Shakespeare and the Fiction of the Intercultural." Eds. Barbara Hodgdon and W.B. Worthen. A Companion to Shakespeare and Performance. Malden, MA: Blackwell: 527-549.

How to cite this article:

Muñoz Valdivieso, Sofía. "'Mine ear is much enamour'd of thy note:' Shakespeare's intercultural dream in the Indian subcontinent." SEDERI 19 (2009): 99-119.

Author's contact: simunoz@uma.es

Submission: 15/11/2008

Acceptance: 18/02/2009 